\title{
Harmful Damage of Enhanced Danger: Economic and Legal Aspects
}

\section{Yurii Ivanov ${ }^{1}$, Oksana Kurilina ${ }^{1}$, Tetiana Protsiuk ${ }^{2}$, Elvira Podoliak ${ }^{3}$, Oleksandra Khytra ${ }^{4}$}

${ }^{1}$ National Academy of Internal Affairs

1 Solomyanska Square, Kyiv, 03035, Ukraine

${ }^{2}$ Academy of Financial Monitoring

24 Biloruska Street, Kyiv, 04050, Ukraine

${ }^{3}$ Lviv University of Business and Law

99 Kulparkivska Street, Lviv, 79021, Ukraine

${ }^{4}$ Lviv State University of Internal Affairs

26 Horodotska Street, Lviv, 79007, Ukraine

DOI: $10.22178 /$ pos. $37-3$

JEL Classification: K19

Received 25.07.2018

Accepted 10.08.2018

Published online 31.08.2018

Corresponding Author:

Elvira Podoliak

podoliak.elvira@ukr.net

(C) 2018 The Authors. This article

is licensed under a Creative Commons

Attribution 4.0 License @) (1)

Abstract. The article is devoted to the study of the legal nature of liability for damage caused by the source of enhanced danger. The conditions and grounds for liability for damage caused by a source of enhanced danger are considered. Determine the obligation to insure civil liability in obligations to compensate for damage caused by a source of enhanced danger. The scientific novelty is to analyze the national legislation on the legal regime of the source of high danger and to identify the elements of the danger of such sources.

Keywords: source of enhanced danger; damage; civil liability; insurance.

\section{INTRODUCTION}

In conditions of gradual economic development of the state there is a need for legal categories that would allow to find the most effective protection of rights and legitimate the interests of citizens. The Constitution of Ukraine not only proclaims the completeness of socio-economic, political rights and human freedoms, but also obliges to take effective measures on safe living of citizens, to create real conditions for counteracting negative phenomena in accordance with democratic standards. The current level of development of the national economy of our country is characterized by the significant technical potential - machines, mechanisms, production equipment, various tools, construction structures. Along with unconditionally useful properties, the exploitation of sources of increased danger is as- sociated with the possibility of causing damage to the life and health of individuals, their property, as well as the property of legal entities. The harm caused by the harmful properties of the source of the enhanced danger, through which the person cannot fully control over it, and therefore completely avoid dangerous circumstances that lead to the negative consequences directly related to the task of harm.

The urgency of the study is due to the fact that the exit from the control of exploitation of the source of enhanced danger leads to negative economic consequences through causing damage to third parties, as well as owners of such sources. The theoretical questions of the obligation to reimburse the damage caused by the use of the law significantly affect the legal practice, since their solution determines the correct application of 
law in the area under consideration, which determines the protection of the vital interests of citizens, society and the state. The improvement of the theoretical provisions concerning the main aspects of compensation for damage caused by the interaction of the source of enhanced danger, expands the practical possibilities of civil law protection of the rights and interests of individuals and legal entities.

Today, one of the tools of protection of the rights and interests of victims as a result of the negative influence of the source of enhanced danger is the mandatory insurance of civil liability of the owners of the source of enhanced danger. Article 7 of the Law of Ukraine "On Insurance" of March 7, 1996, No. 85/96-BP defines the types of compulsory insurance in Ukraine. In particular, the types of compulsory insurance include personal insurance against accidents in transport; insurance of civil liability of owners of land vehicles; insurance of civil liability of economic entities for the damage that may be caused by the fire and accidents at objects of high danger, including fire and explosive objects, economic activity of which may lead to the accidents of ecological and sanitaryepidemiological nature; liability insurance of dog owners (in the list of breeds specified by the Cabinet of Ministers of Ukraine) regarding the damage that may be caused to third parties; civil liability insurance of citizens of Ukraine having the property or other legal possession of weapons for the damage that may be caused to a third party or its property as a result of possession, possession or use of this weapon, etc.

The purpose of the paper is to study the legal nature of the "source of increased danger" in accordance with the provisions of Ukrainian legislation and jurisprudence in this area. Determination of enhanced danger sources types can help with the economic analysis of the current state of the insurance market civil liability of owners of such sources in the future.

\section{LITERATURE REVIEW}

The analysis of recent publications proves that the issue of tort liability for damage caused by the source of enhanced danger became the subject of scientific analysis. In her study, O. L. Zhukovska conducted an analysis of the concept of increased danger, defined the characteristics, the main of which does not allocate the control of sources of enhanced danger. Concern- ing the safety of the operation of vehicles, the scientist highlights the following: guilty behavior of pedestrians, poor road conditions, poor car maintenance of cars by service stations, imperfect constructions of motor vehicles, and especially emphasizes the subjective factor of the state of emergency - gross driver's violation of the Road Rules [1].

Tereshchenko N. carried out the analysis of the Institute for the compensation of damage caused by the source of increased danger, examines the process of formation and development of the institution of liability for causing damage to the source of increased danger, determines the grounds for the emergence of obligations as a result of damage to the source of increased danger and the peculiarities of their subjective composition [2].

Pendiyah G. L. has devoted her dissertation to a comprehensive study of the peculiarities of the Institute of tort liability, in particular, on the reimbursement of damage caused by the source of enhanced danger. The author has investigated the concepts and features of sources of enhanced danger, the grounds for liability for damage caused by the source of enhanced danger determined the specifics of civil liability for causing harm to certain types of sources of enhanced danger, in particular, nuclear torts, toxic torts and auto-delicts, including in separate systems of law [3].

Lesko Y. V. has investigated the peculiarities of compensation for damage caused by the interaction of vehicles; has identified special features of the obligations for compensation for damage caused by the interaction of vehicles and the division of these obligations, depending on the type of vehicle; has clarified the grounds and conditions for the obligation to indemnify the damage caused by the interaction of vehicles; has characterized the objective conditions for the occurrence of these obligations (damage, activities of the person associated with the vehicle, causal relationship); has disclosed the features of guilt in obligations to compensate for damage caused by the interaction of vehicles; has defined the subjects of compensation for damage caused by the interaction of vehicles; has characterized the insurance of civil liability in obligations for compensation for damage caused by the interaction of vehicles; has revealed the peculiarities of the grounds for exemption from the obligation to compensate for the damage caused by the inter- 
action of vehicles [4]. The peculiarity of the data to the studies is their diversity and the availability of different approaches to the identification of these characteristics. At the same time, this issue cannot be considered as finally solved, including due to the lack of a legislative list of sources of enhanced danger.

\section{MATERIALS AND METHODS}

The article uses the regulatory legal acts running the relations in the sphere of the use of high-risk sources, as well as scientific publications devoted to this topic. In the course of the study, methods of formal-logical (dogmatic), systemic, functional, historical and comparative analysis, interpretation of the norms of law, which allowed to determine the peculiarities of compensation for damage caused by the source of increased danger, were used.

\section{RESULTS AND DISCUSSION}

Nowadays, according to Part 1 of Art. 1187 of the Civil Code of Ukraine (hereinafter - the Central Committee of Ukraine), the source of enhanced danger is the activity connected with the use, storage or maintenance of vehicles, mechanisms and equipment, the keeping of chemical, radioactive, explosive, flammable and other substances, the maintenance of wild animals, serving dogs and fighting dogs, etc., which poses an enhanced danger to the person who carries out this activity and other people.

Since this norm does not contain an exhaustive list of types of sources of enhanced danger (types of increased hazardous activities), then in Resolution of the Plenum of the High Specialized Court of Ukraine on Civil and Criminal Matters dated March 1, 2013, No. 4 (hereinafter - Resolution dated March 1, 2013, No. 4) is given Explaining that the special properties of objects, substances or other objects used in the process of activity, have the right to be recognized as a source of enhanced danger of also other activities. These special properties should include the creation of increased probability of harm because of the impossibility of full control over them from people. Civil liability for damage caused by activities that are a source of enhanced danger occurs in the event of its purpose (for example, the use of vehicles for their intended purpose), as well as the involuntary manifestation of the harmful properties of objects used in this activity (for example, in case of damage caused by involuntary traffic). In other cases, the damage is compensated on the general grounds stipulated by Article 1166 of the Civil Code of Ukraine, the person who caused it (for example, when the passenger, opening the door of a non-moving car, caused bodily harm to a person passing by).

Among the main features that determine the source of the enhanced danger they should include the lack of control over sources of enhanced danger, the possibility of accidental damage [2]. It is the presence of properties that are not endowed by anyone at this stage in the development of science and technology (high speed, temperature, weight, energy, etc.), and it increases the likelihood of harm, even with full respect for safety standards.

In other words, these properties are due to incomplete control of the person and high probability of causing harm. G. L. Pendiaga believes that control as a significant and determinative influence on the property benefit or behavior of individuals, ensuring the obtaining of the foreseen legal result is a determining sign of the concept of a source of enhanced danger. At the same time, control over the sources of enhanced danger involves monitoring its own activities and is carried out through the use of safety rules for dealing with a certain category of data sources [5].

Antimonov B. S. suggests that the source of enhanced danger is characterized by the fact that the emergence of a harmful result is determined, as a rule, not by the behavior of the person (causing harm, the victim), and the determining cause in such cases is the activity of a particular kind. For the recognition of activities as a source of enhanced danger it does not matter what the nature of activity is: production, economic, research or administrative and managerial "[6].

Therefore, the sources of enhanced danger are the subject to special rules for their use. Thus, in accordance with the Road Traffic Rules (approved by the Cabinet of Ministers of Ukraine from October 10, 2001, No. 1306), a driver of a motor vehicle, while driving a vehicle, must hold a driver's license for the right to drive a vehicle of the appropriate category; owners of dogs, predatory animals are obliged to register them, remove dogs from living and isolated premises, as well as isolated areas into common courtyards or on the street (with the obligatory safety of people) only 
on a short leash and in a muzzle, except for small breed dogs, on which a corresponding mark was made in the registration certificates (Rules for keeping dogs, cats and predatory animals in settlements of the Ukrainian SSR: Order of the Ministry of Housing and Communal Services of the Ukrainian SSR, Ministry of Agriculture of the Ukrainian SSR, the Minister Health Care of the UkrSSR from 17.06.1980).

In accordance with Article 21 of the Law of Ukraine "On Compulsory Insurance of Civil Liability of Owners of Land Vehicles" of July 1, 2004, No. 1961-IV, the use of a vehicle without a policy of compulsory civil liability insurance is prohibited in Ukraine, that is, the owner vehicles, except for persons exempted from compulsory insurance of civil liability in accordance with clause 13.1 of Article 13 of this Law, are obliged to insure the risk of their civil responsibility that may occur as a result of damage to life, health or property of other persons using vehicles.

The Law of Ukraine "On Occupational Safety" of October 14, 1992, No. 2694-XII stipulates that, in the presence of the conclusion of a psychophysiological examination, persons are allowed to perform work of high danger and those who need professional selection. In addition, all employees are the subject to compulsory state social insurance against accidents at work and occupational diseases which have caused disability (Article 5 of the Law) according to the law. However, the employer must obtain permission to carry out work of high danger and for the operation (application) of machines, mechanisms, equipment of high danger. The procedure for the issuance of permits to carry out the work of increased danger and for the operation (application) of machines, mechanisms, equipment of increased danger is provided by the decree of the Cabinet of Ministers of Ukraine dated October 26, 2011, No. 1107.

The operation of this Procedure does not apply to state emergency rescue services and their formation, which have been certified in accordance with the established procedure, as well as military management bodies, military units, military educational establishments, institutions and organizations of the Armed Forces, other military formations formed in accordance with laws and in which hired workers are not involved in performing work of high danger and / or operation (application) of machines, mechanisms, equipment of enhanced danger.
For the first time the classification of sources of increased danger was proposed by 0 . Krasavchikov. He subdivided all sources of high-risk into such kinds as: physical; physical and chemical; chemical; biological [7]. Physical sources of enhanced danger, cause mechanical, thermal, electrical and other physical effects on the environment, therefore, they are in turn subdivided into subspecies. Mechanical sources of high hazard include various mechanical industrial units, mechanical transport hoists, and the like. To the thermal one is the most diverse production equipment, operation of which is associated with high temperatures (aggregates of hot shops open-hearth, blast furnaces, rolling mills (hot rolling), etc.). Electricity sources of high danger include the relevant equipment of power plants producing this type of energy, as well as the following links of the power system that transmit current to consumers (transformer substations, relay protection equipment, power lines, etc.).

Among the chemical sources of high hazard they include the poisonous substances (which may cause negative chemical effects on humans or animals - poisonous substances, chemical reagents used in laboratories, potent medical preparations, etc.), the explosive and flammable substances.

The physico-chemical sources of high danger include all the various installations and aggregates capable of producing radiation in dangerous doses for humans, various reactors, engines working on atomic fuels, etc. - that is, all industrial or research units and equipment that create radioactivity in dangerous doses.

The biological sources of high danger, in turn, are divided into: zoological and microbiological. The zoological sources of increased danger include animals that are in the possession of man and constitute an increased danger (wild animals, large dogs, etc.). The second subgroup of the biological sources of enhanced danger are the microbiological sources, which are separate microorganisms (strains, viruses, bacteria, etc.).

The source of the enhanced danger is the recognition of any activity, the realization of which creates a high probability of causing harm due to the impossibility of controlling it by a person, as well as activity on the use, transportation, storage of objects, substances and other objects of industrial, economic or other purpose, which have the same properties. Property liability for damage caused by the actions of such sources 
should occur both in the purposeful use of them and in the event of involuntary manifestation of their harmful properties (for example, in case of damage caused by the involuntary movement of the car) (paragraph 4 of the Resolution of the Plenum of the Supreme Court of Ukraine "On Practice consideration by civil courts in claims for damages "dated March 27, 1992 No. 6 - further Decree No. 6 dated March 27, 1992).

Thus, the legal nature of the source of enhanced danger is due to defining features, in particular: the exclusion of the possibility of complete, objective, comprehensive control over the effect of a source of enhanced danger; the risk of causing harm, the probability of causing accidental damage; an increased risk of damage caused by exploitation of a source of enhanced danger [3].

In accordance with Part 3 of Art. 16 of the Law of Ukraine "On Transport" dated November 10, 1994 No. 232/94-BP, the part of the territory of enterprises, stations, stations, ports, wharves, airfields and routes where traffic is being carried out, maneuvering and loading operations are carried out, is areas of enhanced danger. In the bands of air approaches to airfields, the construction of high-risk objects may be restricted (Part 7 of Article 69 of the Air Code of Ukraine).

The duty to compensate for the damage caused by the enhanced danger is borne by the owner of the source of enhanced danger, that is, a person who, on the relevant legal basis (property right, other property right, contract, rent, etc.) has a vehicle, mechanism, or other object, the use, storage or maintenance of which creates an enhanced danger (Part 2 of Article 1187 of the Civil Code of Ukraine). The subjects of the obligation can act as physical and legal persons. If a person has a driver's license for the right to drive a vehicle of the relevant category and a registration document for a vehicle transferred to it by the owner or another person who legally uses such a vehicle, then this person will be liable for damages (paragraph 2.2 of the Rules of the Road of Ukraine).

A person, who carries out activities that is a source of enhanced danger and is not liable for damage to the victim by a person who directs a vehicle in connection with the performance of his labor (official) duties on the basis of an employment contract (contract) from a person who, on the appropriate legal basis (property right, other property rights, contract, rent, etc.) owns a vehicle if a civil-law agreement has been concluded with it, is not considered. Such a person, taking into account the nature of the relations between them, may be brought to the employer's liability only in a regressive manner in accordance with Article 1191 of the Civil Code of Ukraine. However, if a citizen was forbidden to manage a source, and he used it for personal purposes without permission, then this act will be considered as the illegal possession and the citizen will be obliged to compensate for damage in accordance with Art. 1187 of the Civil Code of Ukraine. A physical or legal person who has compensated the damage caused by his employee by performing labor (official) duties on the basis of an employment contract (contract) or a civil law contract has the right to reverse the claim (recourse) to such employee - the actual harm causor - in the amount of the compensation paid, if another amount is not established by the law (part 1 of Article 1191 of the Civil Code of Ukraine).

The damage caused to a person and property of a citizen or caused to property of a legal entity, when this was the result of the operation of a source of high danger, shall be fully compensated by the person who caused it, regardless of the existence of the fault (paragraph 2 of the Resolution dated March 27, 1992, No. 6). The property liability for damage caused by the actions of such sources should occur both in the purposeful use of them and in the event of involuntary manifestation of their harmful properties (for example, in the case of damage caused by the unintentional movement of the car).

The enterprise of transport, which activities are associated with increased danger, bears material liability for damage caused by the death or damage to the health of the passenger during the use of transport (Part 2 of Article 13 of the Law of Ukraine "On Transport").

The unlawful seizure of a source of enhanced danger, is the reason for the release of the owner of the responsibility of the source of enhanced danger (Part 3 of Article 1187 of the Civil Code of Ukraine). Thus, the owner of a source of enhanced danger is not liable for the damage caused by this source if it proves that it has left its possession as a result of the wrongful acts of other persons, and not by its fault. The people who committed these illegal actions compensate for the damage caused by the owners of the responsibility of the sources of high danger under the rules of liability of owners, and when this was facilitated by the owner's guilty conduct (proper 
security was not provided, etc.), the responsibility for the damage caused by the source of enhanced danger may be imposed to the person who illegally seized this source, and on his owner according to the degree of blame for each of them.

When causing damage to a source of enhanced danger, its owner cannot be obliged to reimburse it if it arose as a result of force majeure or intent of the victim (Part 5 of Article 1187 of the Civil Code of Ukraine), and in cases stipulated by a special law, only intention of the victim. Under an irresistible force one should understand, in particular, the extraordinary or inevitable under the given circumstances of the event (clause 1 Part 1 of Article 263 of the Civil Code of Ukraine), that is, those that are of an external nature. Under the will of the victim should be understood, in particular, such an unlawful behavior, when the victim not only foresees, but also wishes or deliberately admits a harmful result (for example, a suicide).

If gross negligence of the victim has contributed to the occurrence or increase of harm, depending on the degree of the victim's fault, unless otherwise is provided by the law, the amount of compensation from the person who carries out an activity that is a source of enhanced danger should be reduced (but the compensation damage cannot be completely denied). The question of whether a victim of gross negligence is permissible (Part 2 of Article 1193 of the Civil Code of Ukraine) must be decided on a case-by-case basis in the light of the actual circumstances of the case (the nature of the action, the circumstances of the harm, the individual characteristics of the victim, its condition, etc.). Provisions of Art. 1193 of the Civil Code of Ukraine on the reduction of the amount of compensation, taking into account the degree of guilt of the victim, applies in other cases to the damage to property, as well as to an individual, however in each case the reason for this may be gross negligence of the victim (being drunk, neglecting traffic safety rules, etc.), rather than simple recklessness. In itself, staying in a drunken state is not an example of gross negligence, if there were no violations of the Road Rules. Rules of Part 4 of Art. 1193 of the Civil Code of Ukraine on the possibility of reducing the amount of compensation for damage inflicted by an individual, depending on its financial situation, except in cases where the damage was caused by a crime, apply in exceptional cases, if the indemnification of the damage in full amount is impossible or put the defendant in a difficult financial situation. In addition, a reduction in the amount of responsibility of the person charged with the obligation to compensate for damage caused by injury or other damage to health is possible by its written request, if the efficiency of the victim increased in comparison with which he had at the moment of the decision on the issue of compensation damage (Article 1204 of the Civil Code of Ukraine). In this case, the procedure for proving such circumstances is similar to the procedure for determining the loss of capacity for work. The victim's guilt is not taken into account in the case of reimbursement of additional expenses provided for in part one of Article 1195 of the Civil Code of Ukraine, in the event of compensation for damage caused by the death of the breadwinner, and in the event of reimbursement of the cost of burial (paragraph 7 of the Regulation as of March 1, 2013 No. 4).

However, in accordance with international law, responsibility for the damage caused by special sources of enhanced danger is not excluded by the irresistible force in general, establishes the absolute responsibility of the State launching a space object to compensate for the damage caused by this space object on the surface of the ground or aircraft in flight [8].

If the gross negligence of the victim has contributed to the occurrence or increase of damage, depending on the degree of fault of the victim, unless otherwise specified by law, the amount due from the owner of the source of increased danger of reparation should be reduced or compensation for damage should be denied. Reducing the amount of compensation or refusing to reimburse the damage, taking into account the extent of the victim's guilt, applies in other cases to the damage of property as well as to the citizen's person, however in each case the reason for this may be gross negligence of the victim (being in a state of drunk, neglecting traffic safety rules and etc.), rather than simple recklessness.

\section{CONCLUSIONS}

In Part 1 of Art. 1187 of the Civil Code of Ukraine fixed only an approximate list of sources of enhanced danger: vehicles, mechanisms and equipment, chemical, radioactive, explosive and flammable and other substances, wild animals, servicing dogs and fight dogs, etc. As it has been mentioned, their exhaustive list cannot be in- 
ferred due to the constant development of science and technology. It is precisely in the absence of an exclusive list in practice that there is a need to resolve the issue that can be attributed to a source of enhanced danger, and that this list is not included. The most characteristic features of the source of enhanced danger are: the impossibility of complete control on the part of man; the presence of harmful properties; the great probability of harm. The notion of a source of enhanced danger should be regarded as a combina- tion of two elements: 1) the certain material object; 2) the activities on its use. Currently, the liability insurance of owners of sources of enhanced risk in Ukraine is in the stage of formation. Enterprises and the population do not perceive such insurance as a risk management mechanism. However, the real socio-economic situation requires a well-developed, full-fledged protection mechanism that will allow the insurance company to reimburse victims the damage caused by sources of enhanced danger.

\section{REFERENCES}

1. Zhukovskaya, O. L. (1994). Vozmeshhenie vreda, prichinennogo istochnikom povyshennoj opasnosti: nekotorye aspekty problemy [Compensation for damage caused by a source of increased danger: some aspects of the problem]. Moscow: Prosveshhenie (in Russian) [Жуковская, А. Л. (1994). Возмещение вреда, причиненного источником повышенной опасности: некоторые аспекты проблемы. Москва: Просвещение].

2. Tereshchenko, N. V. (2003). Osoblyvosti vidpovidalnosti za shkodu, zapodiianu dzherelom pidvyshchenoi nebezpeky [Characteristics of liability for damage caused by a source of increased danger] (Doctoral thesis). Kharkiv: Natsionalnyi universytet vnutrishnikh sprav (in Ukrainian) [Терещенко, Н. В. (2003). Особливості відповідальності за шкоду, заподіяну джерелом підвищеної небезпеки (Автореферат кандидатської дисертації). Харків: Національний університет внутрішніх справ].

3. Pendyaga, G. L. (2006). Vidpovidalnist za shkodu, zapodiianu dzherelom pidvyshchenoi nebezpeky [The liability for damage, caused by source of increased danger] (Doctoral thesis). Retrieved from https://bit.ly/2PqJiYE (in Ukrainian) [Пендяга, Г. Л. (2008). Відповідальність за шкоду, заподіяну джерелом підвищеної небезпеки (Автореферат кандидатської дисертації. URL: https://bit.ly/2PqJiYE].

4. Lesko, Yu. V. (2017). Vidshkoduvannia shkody, zavdanoi vnaslidok vzaiemodii transportnykh zasobiv [Indemnification, caused owing to interaction of vehicles] (Doctoral thesis). Retrieved from http://ekhnuir.univer.kharkov.ua/bitstream/123456789/12525/2/aref-Lesko.pdf (in Ukrainian)

[Лесько, Ю. В. (2017). Відшкодування шкоди, завданої внаслідок взаємодії транспортних засобів (Автореферат кандидатської дисертації). URL: http://ekhnuir.univer.kharkov.ua/bitstream/123456789/12525/2/aref-Lesko.pdf].

5. Pendyaga, G. L. (2006). Pravova katehoriia kontroliu yak osoblyva umova vyznachennia dzherela pidvyshchenoi nebezpeky [Legal category of control as a special condition for determining the source of increased danger]. Byuleten Ministerstva yustytsiyi Ukrayiny, 5, 139-143 (in Ukrainian) [Пендяга, Г.Л. (2006). Правова категорія контролю як особлива умова визначення джерела підвищеної небезпеки. Бюлетень Міністерства юстиції України, 5, 139-143].

6. Antimonov, B. S. (1952). Grazhdanskaja otvetstvennost' za vred, prichinennyj istochnikom povyshennoj opasnosti [Civil responsibility for harm caused by a source of increased danger]. Moscow: Gosjurizdat (in Russian)

[Антимонов, Б. С. (1952). Гражданская ответственность за вред, причиненный источником повышенной опасности. Москва: Госюриздат].

7. Krasavchikov, O. A. (1966). Vozmeshhenie vreda, prichinennogo istochnikom povyshennoj opasnosti [Compensation of harm caused by a source of increased danger]. Moscow: Juridicheskaja literatura (in Russian)

[Красавчиков, О. А. (1966). Возмещение вреда, причиненного источником повышенной опасности. Москва: Юридическая литература]. 
8. United States Department of Transportation. (n. d.). Convention of International Liability for Damage Caused by Space Objects. Retrieved from July 1, 2018, from

https://www.faa.gov/about/office_org/headquarters_offices/ast/media/Conv_International_Lia b_Damage.pdf 